\title{
Kinetic and Thermodynamic Analysis of Two Carboxymethylcellulases from Macrotermes subhyalinus Little Soldier
}

\author{
Jean B. Fagbohoun ${ }^{1}$, Mankambou J. Gnanwa ${ }^{2}$, Fankroma M. T. Koné3, S. Dabonné ${ }^{3}$ \& Patrice L. Kouamé3 \\ ${ }^{1}$ Laboratory of Biochemistry-Genetics, University Peleforo Gon Coulibaly, BP 1328 Korhogo, Côte d'Ivoire \\ ${ }^{2}$ Laboratory of Biochemistry and Microbiology, University Jean Lorougnon Guede, BP 150 Daloa, Côte d'Ivoire \\ ${ }^{3}$ Laboratory of Biocatalysis and Bioprocessing, Department of Food Science and Technology, University Nangui \\ Abrogoua, 02 BP 801 Abidjan 02, Côte d'Ivoire
}

Correspondence: Fankroma M. T. Koné, Laboratory of Biocatalysis and Bioprocessing, Department of Food Science and Technology, University Nangui Abrogoua, 02 BP 801 Abidjan 02, Côte d'Ivoire. Tel: 225-4803-8466. E-mail: fankrom@yahoo.fr

Received: July 26, 2017

Accepted: August 5, 2017

Online Published: August 28, 2017

doi:10.5539/ijb.v9n4p17

URL: https://doi.org/10.5539/ijb.v9n4p17

\begin{abstract}
Optimization of thermal processes relies on adequate degradation kinetic models to warrant food safety and quality. The knowledge on thermal inactivation of enzymes is necessary to allow their proper utilization in food industry and technology applications, enabling the reduction of heating times and optimization of heating temperatures. In this work, the kinetic of thermal inactivation was studied for the previously characterized carboxylmethylcellulases Ab-CX1 and Ab-CX2 from Macrotermes subhyalinus little soldier. Samples of carboxymethylcellulases were treated at different time-temperature combinations in the range of 5-60 min at $50-65^{\circ} \mathrm{C}$ and the kinetic and thermodynamic parameters for carboxymethylcellulases were calculated. Results showed that inactivation followed a first-order reaction with $\mathrm{k}$-values between $0.0103 \pm 0.0003$ to $0.1217 \pm 0.0005$ and $0.0149 \pm 0.0007$ to $0.0416 \pm 0.0003 \mathrm{~min}^{-1}$ for $\mathrm{Ab}-\mathrm{CX} 1$ and $\mathrm{Ab}-\mathrm{CX} 2$, respectively. At high temperatures, $\mathrm{Ab}-\mathrm{CX} 2$ was less resistant, with a significant decrease in residual activity compared to Ab-CX1. The $D$ - and $k$-values decreased and increased, respectively, with increasing temperature, indicating faster inactivation of carboxymethylcellulases. Activation energy $(E a)$ and $Z$-values were estimated to $76.74 \pm 1.98 \mathrm{~kJ}^{-\mathrm{mol}^{-1}}$ and $24.21 \pm$ $1.92{ }^{\circ} \mathrm{C}$ for Ab-CX1, $62.80 \pm 2.05 \mathrm{~kJ}^{\mathrm{mol}} \mathrm{l}^{-1}$ and $33.33 \pm 2.78^{\circ} \mathrm{C}$ for Ab-CX2. Thermodynamic parameters $\left(\Delta H^{\#}\right.$, $\Delta S^{\#}$ and $\Delta G^{\#}$ ) were also calculated. The high value obtained for the variation in enthalpy of activation indicates that a high amount of energy is required to initiate denaturation, probably due to the molecular conformation of carboxymethylcellulases. All results suggest that both carboxymethylcellulases are relatively resistant to long heat treatments up to $50^{\circ} \mathrm{C}$.
\end{abstract}

Keywords: carboxymethylcellulases, kinetic parameters, Macrotermes subhyalinus, thermal stability, thermodynamic parameters

\section{Introduction}

Cellulose is the major component of plant biomass. It is a linear biopolymer consisting of anhydroglucopyranose molecules (glucose) connected by $\beta-1,4$-glycosidic bonds (Hong et al., 2012) and its molecules (polymer) vary widely in length and are usually arranged in bundles or fibrils (Haruta et al., 2002; Walsh, 2002). In nature, the hydrolysis of cellulose requires the synergistic action of cellulases, which include: endoglucanase, exoglucanase and $\beta$-glucosidase (Fagbohunka et al., 2017). In recent decades, the interest in hemicellulases and cellulases has increased due to the ethanol production from lignocellulosic residues (De Almeida et al., 2011). Thus, cellulases have several potential applications in industries like biofuel, textile, paper, feeds, fruits and vegetables (Zaldivar et al., 2001; Fagbohunka, et al., 2017). These enzymes are also used for non-specific cleavage of chitosan to release oligosaccharides with low molecular mass (Xia et al., 2008). Therefore, cellulases have been widely used in food and pharmaceutical industries and also for controlling environmental pollution (Jabbar et al., 2008; Niaz et al., 2011). In addition, cellulases have a wide range of industrial applications such as the treatment of starch processing, animal feed production, grain alcohol fermentation, fermentation, malting and brewing, extraction of fruit and vegetable juices, pulp and paper industry and textile industry (Ögel et al., 2001; Adsul et al., 2007; Kaur et al., 2007; Papinutti \& Forchiassin, 2007). Based on the importance of lignocellulose-degrading enzymes, many 
authors have attempted to purify and characterize these enzymes in some microorganisms (Lama et al., 2004; Ninawe et al., 2008; Gaffney et al., 2009) and insects (Séa et al., 2006; Binate et al., 2008; Arakawa et al., 2009; Blei et al., 2010; Fagbohoun et al., 2012; Fagbohunka, et al., 2017).

But, for industrial applications, enzymes must be stable under process conditions. Generally, enzymes are preferred over chemical catalysts. Therefore, thermophilic microorganisms are believed to be potentially good alternative sources of thermostable enzymes (Egas et al., 1998). Therefore, thermostable enzymes have been reported to have higher stability to organic solvent, alkaline and acidic $\mathrm{pH}$ and detergents (C. Vieille et al., 1996). Other benefits include enhancement of reaction rate constant, increasing the diffusion rate as the medium viscosity decreases with an increasing temperature (Kumar \& Swati, 2001). Thus, one of the ways to identify enzymes which are thermally stable is to exploit natural sources such as both thermophilic and mesophilic organisms. Thermophilic organisms are known to produce enzymes having higher thermostability than those derived from their mesophilic counterparts (George et al., 2001). In this regard, comparative studies of thermophilic and mesophilic enzymes have demonstrated that weak interactions such as hydrogen bonds (Macedo-Ribeiro et al., 1996), disulfide bonds (Hopfner et al., 1999), ion pairs (Vetriani et al., 1998), salt bridges (Criswell et al., 2003), hydrophobic interactions (Elcock, 1998) and compactness (Russell et al., 1997) are important for stability. Therefore, enhancement of the structural stability of enzymes is of great importance for their application in several industrial processes. Thus, any process that enhances the structural stability and reaction rate of enzymes has a favorable impact on their industrial application (Sousa, 1995; Matsumoto et al., 1997).

In previous study, we purified to homogeneity monomeric carboxymethylcellulases from little soldier of termites Macrotermes subhyalinus (Fagbohoun, et al., 2012). However, there is no report concerning thermal stability of these cellulases. Thus, the knowledge on kinetics of thermal inactivation of two carboxymethylcellulases Ab-CX1 and $\mathrm{Ab}-\mathrm{CX} 2$ is important to allow their suitable utilization as biocatalysts in industry. Therefore, the aim of this work was to evaluate the stability, then to determinate kinetic and thermodynamic parameters of carboxymethylcellulases Ab-CX1 and Ab-CX2.

\section{Material and Methods}

\subsection{Enzymes}

Carboxymethylcellulases (Ab-CX1 and Ab-CX2) used in this study were previously purified from little soldier of Macrotermes subhyalinus (Fagbohoun, et al., 2012; Fagbohoun, 2013). Theses enzymes were homogeneous on polyacrylamide-gel electrophoresis in the absence of sodium dodecyl sulphate (SDS).

\subsection{Carboxymethylcellulases Assays}

Under the standard test conditions, cellulase activity was assayed spectrophotometrically by measuring the release of reducing sugars from carboxymethylcellulose (CMC) (Fagbohoun, et al., 2012; Fagbohoun, 2013). The essay mixture $(0.38 \mathrm{~mL})$ containing $0.2 \mathrm{~mL}$ of CMC $(0.5 \%$, w/v) in $20 \mathrm{mM}$ sodium acetate buffer $(\mathrm{pH} 5.0)$ with $0.1 \mathrm{~mL}$ enzyme solution, was incubated at $45^{\circ} \mathrm{C}$ for $30 \mathrm{~min}$. The reaction was stopped by adding $0.3 \mathrm{~mL}$ of dinitrosalicylic acid solution and heating for $5 \mathrm{~min}$ in boiling water bath. The absorbance was measured at $540 \mathrm{~nm}$ after cooling on ice for $5 \mathrm{~min}$.

One unit (U) of enzyme activity was defined as the amount of enzyme capable of releasing one $\mu$ mol of reducing sugar per min under the defined reaction conditions. Specific activity was expressed as units per $\mathrm{mg}$ of protein ( $\mathrm{U} / \mathrm{mg}$ of protein).

\subsection{Protein Determination}

Protein was determined according to Lowry method (Lowry et al., 1951) using bovine serum albumin as standard.

\subsection{Thermal Inactivation}

Thermal inactivation of each carboxymethylcellulase was investigated at various constant temperatures from 50 to $65^{\circ} \mathrm{C}$ after exposure to each temperature for a period of 5 to $60 \mathrm{~min}$. The enzyme was heated in sealed tubes, which was incubated in $100 \mathrm{mM}$ sodium acetate buffer ( $\mathrm{pH}$ 5.0) in a thermostatically controlled water bath. Tubes were withdrawn at each time intervals and immediately immersed in an ice bath, in order to stop heat inactivation. The residual enzymatic activity, determined in both cases at $37^{\circ} \mathrm{C}$ under the standard test conditions, was expressed as percentage activity of zero-time control of the untreated enzyme.

\subsection{Kinetic Data Analysis}

First-order kinetic has been reported to describe thermal inactivation of carboxymethylcellulases (Guiavarc'h et al., 2002). The integral effect of inactivation process at constant temperature, where the inactivation rate constant is independent of time, is given in Eq. 1: 


$$
\ln (A t / A 0)=-k t
$$

where, $A t$ is the residual enzyme activity at time $t(\mathrm{~min}), A o$ is the initial enzyme activity, $k\left(\mathrm{~min}^{-1}\right)$ is the inactivation rate constant at a given condition. $k$-values were obtained from the regression line of $\ln (A t / A o)$ versus time as slope.

$D$-value is defined as the time needed, at a constant temperature, to reduce the initial enzyme activity $(A o)$ by $90 \%$. For first-order reactions, the $D$-value is directly related to the rate constant $k$ (Eq. 2) (Stumbo, 1973; Espachs-Barroso et al., 2006):

$$
D=2.303 / k
$$

The $Z$-value $\left({ }^{\circ} \mathrm{C}\right)$ is the temperature increase needed to induce a 10 -fold reduction in $D$-value (Stumbo, 1973). This $Z$-value follows the Eq. 3:

$$
\log (D 1 / D 2)=(T 2-T 1) / Z
$$

where, $T 1$ and $T 2$ are the lower and higher temperatures in ${ }^{\circ} \mathrm{C}$ or $\mathrm{K}$. Then, $D 1$ and $D 2$ are $D$-values at the lower and higher temperatures in min, respectively.

The $Z$-values were determined from the linear regression of $\log (D)$ and temperature $(T)$.

\subsection{Thermodynamic Analysis}

The Arrhenius equation is usually utilized to describe the temperature effect on the inactivation rate constants and the dependence is given by (Eq. 4 or 5):

or

$$
\begin{gathered}
k=A \exp (-E a / R T) \\
\ln k=\ln A-(E a / R T)
\end{gathered}
$$

where, $k$ is the reaction rate constant value, $A$ the Arrhenius constant, $E a\left(\mathrm{~kJ} \mathrm{~mol}^{-1}\right)$ the activation energy, $R(8.31$ J.mol-1 $\mathrm{K}^{-1}$ ) the universal gas constant and $T(\mathrm{~K})$ the absolute temperature.

When $\ln k$ is plotted versus the reciprocal of the absolute temperature, a linear relationship should be observed in the temperature range studied. The slope of the line obtained permitted to calculate the $E a$ and the ordinate intercept corresponds to $\ln A$ (Dogan et al., 2002). The values of activation energy $(E a)$ and Arrhenius constant $(A)$ allowed the determination of different thermodynamic parameters such as variations in enthalpy $\left(\Delta H^{*}\right)$, entropy $\left(\Delta S^{\sharp}\right)$ and Gibbs free energy $\left(\Delta G^{\sharp}\right)$ according to following equations (Eq. $\left.6 ; 7 ; 8\right)$ :

$$
\begin{gathered}
\Delta H^{\#}=E a-R T \\
\Delta S^{\#}=R(\ln A-\ln K B / h-\ln T) \\
\Delta G^{\#}=\Delta H^{\#}-T \Delta S^{\#}
\end{gathered}
$$

where, $K B\left(1.38 \times 10^{-23}{\left.\mathrm{~J} . \mathrm{K}^{-1}\right)}^{-1}\right.$ is the Boltzmann's constant, $h$ the Planck's constant $\left(6.626 \times 10^{-34} \mathrm{~J} . \mathrm{s}\right)$ and $T$ the absolute temperature.

\subsection{Statistical Analyses}

Statistical analyses were carried out in triplicate. Results were expressed as means \pm standard deviation. The statistical differences among the means of data were calculated using one-way analysis of variance (ANOVA) and Duncan's Multiple Range Test (DMRT). Significance was set at $\mathrm{P}<0.05$.

\section{Results and Discussion}

\subsection{Thermal Inactivation Kinetics of Carboxylmethylcellulases}

We have earlier reported that a new endo-beta-D-glycosidase from salivary glands of Macrotermes subhyalinus little soldier with a dual activity against carboxymethylcellulose and xylan has also been isolated and partially described (Fagbohoun, et al., 2012). In this study, the effect of heat treatment over a range of temperature from 50 to $65^{\circ} \mathrm{C}$ on both carboxymethylcellulases $\mathrm{Ab}-\mathrm{CX} 1$ and $\mathrm{Ab}-\mathrm{CX} 2$ was evaluated by determining the residual percentage activity (Table 1). 
Table 1. Effect of treatment temperature and time on inactivation of carboxymethylcellulases $\mathrm{Ab}-\mathrm{CX} 1$ and Ab-CX2 from little soldier of Macrotermes subhyalinus

\begin{tabular}{|c|c|c|c|c|c|c|c|c|}
\hline \multirow{3}{*}{$\begin{array}{l}\text { Time } \\
(\min )\end{array}$} & \multicolumn{8}{|c|}{ Residual activity $(\%)$ at each temperature $\left({ }^{\circ} \mathrm{C}\right)$ of heat treatment } \\
\hline & \multicolumn{2}{|c|}{50} & \multicolumn{2}{|c|}{55} & \multicolumn{2}{|c|}{60} & \multicolumn{2}{|c|}{65} \\
\hline & $\mathrm{Ab}-\mathrm{CX} 1$ & $\mathrm{Ab}-\mathrm{CX} 2$ & $\mathrm{Ab}-\mathrm{CX} 1$ & $\mathrm{Ab}-\mathrm{CX} 2$ & $\mathrm{Ab}-\mathrm{CX} 1$ & $\mathrm{Ab}-\mathrm{CX} 2$ & $\mathrm{Ab}-\mathrm{CX} 1$ & $\mathrm{Ab}-\mathrm{CX} 2$ \\
\hline 5 & $95.12 \pm 5.11$ & $91.39 \pm 3.19$ & $90.48 \pm 5.90$ & $91.39 \pm 2.34$ & $87.80 \pm 4.18$ & $83.96 \pm 2.89$ & $74.23 \pm 1.52$ & $78.66 \pm 2.19$ \\
\hline 10 & $90.48 \pm 2.53$ & $86.07 \pm 3.12$ & $81.55 \pm 2.11$ & $76.33 \pm 0.74$ & $77.88 \pm 1.89$ & $71.69 \pm 4.17$ & $63.76 \pm 1.45$ & $65.96 \pm 2.14$ \\
\hline 15 & $84.44 \pm 2.89$ & $81.05 \pm 0.65$ & $74.08 \pm 4.51$ & $67.03 \pm 2.38$ & $70.46 \pm 3.22$ & $63.76 \pm 1.24$ & $54.88 \pm 2.17$ & $54.39 \pm 1.47$ \\
\hline 20 & $81.87 \pm 4.51$ & $73.34 \pm 1.22$ & $70.46 \pm 4.41$ & $60.56 \pm 4.57$ & $63.76 \pm 2.17$ & $49.65 \pm 1.98$ & $45.84 \pm 1.22$ & $41.51 \pm 1.31$ \\
\hline 25 & $76.33 \pm 2.88$ & $67.70 \pm 2.82$ & $63.12 \pm 2.87$ & $54.88 \pm 2.38$ & $58.86 \pm 1.59$ & $42.74 \pm 3.15$ & $36.83 \pm 0.76$ & $33.92 \pm 1.68$ \\
\hline 30 & $74.08 \pm 0.34$ & $63.73 \pm 1.66$ & $59.45 \pm 1.59$ & $49.65 \pm 2.67$ & $51.68 \pm 2.55$ & $36.78 \pm 1.52$ & $30.11 \pm 1.59$ & $29.81 \pm 2.55$ \\
\hline 35 & $70.46 \pm 1.26$ & $59.89 \pm 2.92$ & $54.88 \pm 1.14$ & $41.89 \pm 1.75$ & $47.23 \pm 2.68$ & $30.11 \pm 2.36$ & $25.92 \pm 2.33$ & $22.31 \pm 1.17$ \\
\hline 40 & $67.03 \pm 2.60$ & $55.49 \pm 1.45$ & $49.46 \pm 1.67$ & $38.67 \pm 2.07$ & $42.74 \pm 3.19$ & $24.65 \pm 1.37$ & $22.31 \pm 2.51$ & $18.26 \pm 0.25$ \\
\hline 45 & $62.96 \pm 1.03$ & $51.17 \pm 0.34$ & $44.93 \pm 2.55$ & $33.28 \pm 4.21$ & $38.67 \pm 0.11$ & $20.18 \pm 1.96$ & $16.52 \pm 1.81$ & $14.95 \pm 0.56$ \\
\hline 50 & $59.45 \pm 0.25$ & $47.71 \pm 2.01$ & $41.89 \pm 2.31$ & $30.11 \pm 1.49$ & $34.30 \pm 1.22$ & $18.26 \pm 0.52$ & $13.53 \pm 0.17$ & $12.24 \pm 1.22$ \\
\hline 55 & $56.55 \pm 2.17$ & $43.60 \pm 1.01$ & $38.67 \pm 2.29$ & $27.25 \pm 2.92$ & $30.11 \pm 1.38$ & $14.95 \pm 1.33$ & $11.08 \pm 0.25$ & $10.02 \pm 1.05$ \\
\hline 60 & $53.79 \pm 1.76$ & $40.56 \pm 3.52$ & $36.05 \pm 3.15$ & $24.65 \pm 3.17$ & $28.08 \pm 0.25$ & $12.24 \pm 3.11$ & $10.02 \pm 1.01$ & $9.11 \pm 0.11$ \\
\hline
\end{tabular}

The obtained values are mean \pm SD of three independent determinations. On the lines of each parameter, the averages affected of no common letter are significantly different between them on the threshold of $5 \%$ according to the test of Duncan.

Thus, we note an enzyme activity peak usually referred to the optimum temperature and which varies for different enzymes (Trasar-Cepeda et al., 2007). The activity of both carboxylmethylcellulases was decreased with increasing heating time $(5-60 \mathrm{~min})$ and temperature $\left(50-65^{\circ} \mathrm{C}\right)$. Indeed, between 50 to $65^{\circ} \mathrm{C}$, heat-denaturation of $\mathrm{Ab}-\mathrm{CX} 1$ and $\mathrm{Ab}-\mathrm{CX} 2$ occurred after incubation for $5 \mathrm{~min}(95.12 \pm 5.11$ to $74.23 \pm 1.52 \%$ and $91.39 \pm 3.19$ to $78.66 \pm 2.19 \%$, respectively). Thus, the heat treatment at $50^{\circ} \mathrm{C}$ during $60 \mathrm{~min}$ caused a partial inactivation of 53.79 $\pm 1.76 \%$ for $\mathrm{Ab}-\mathrm{CX} 1$ and $40.56 \pm 3.52 \%$ for $\mathrm{Ab}-\mathrm{CX} 2$. A partial inactivation of $51.68 \pm 2.55$ and $36.78 \pm 1.52 \%$ was also observed for $\mathrm{Ab}-\mathrm{CX} 1$ and $\mathrm{Ab}-\mathrm{CX} 2$, respectively, after heating at $60^{\circ} \mathrm{C}$ during $30 \mathrm{~min}$. However, a strong inactivation of both enzyme activities was obtained after $60 \mathrm{~min}$ of heat treatment at $65^{\circ} \mathrm{C}$. Moreover, carboxylmethylcellulases from abdomen of Macrotermes subhyalinus little soldier showed a typical temperature-dependent inactivation profile in the presence of the substrate used. At higher temperature, the enzyme most likely underwent denaturation and lost its activity. Stauffer (1989) states that denaturation is the heat induced spontaneous, irreversible breakdown of the secondary and tertiary structure of the enzyme protein such that the enzyme will no longer function and cannot re-activate. The results of the heat inactivation studies suggest that these enzymes belong to the group of thermostable enzymes. Compared to Ab-CX2, results show that $\mathrm{Ab}-\mathrm{CX} 1$ was the most thermostable because it retained about 50 and $55 \%$ activity after 30 and 15 min at 60 and $65^{\circ} \mathrm{C}$, respectively. Based on the semi-log plots linear of carboxylmethylcellulase activities versus heat treatment time at temperature ranged from 50 to $65^{\circ} \mathrm{C}$ (Table 1), it can be concluded that thermal inactivation described a first-order reaction. These results are in agreement with those reported for peptide cerein 8A (Lappe et al., 2009) and for beta-glucosidase from the digestive juice of the land crab Cardisoma armatum (Ya et al., 2014).

The inactivation rate constant $(k)$ value and half-life $\left(\mathrm{t}_{1 / 2}\right)$ of carboxymethylcellulases $\mathrm{Ab}-\mathrm{CX} 1$ and $\mathrm{Ab}-\mathrm{CX} 2$ from little soldier of Macrotermes subhyalinus are presented in Table 2.

Table 2. $k$-values and $\mathrm{t}_{1 / 2}$ for thermal inactivation of carboxymethylcellulases $\mathrm{Ab}-\mathrm{CX} 1$ and $\mathrm{Ab}-\mathrm{CX} 2$ from little soldier of Macrotermes subhyalinus at temperature range $\left(50-65^{\circ} \mathrm{C}\right)$

\begin{tabular}{ccccc}
\hline \multirow{2}{*}{$\begin{array}{c}\text { Temperature } \\
\left({ }^{\circ} \mathrm{C}\right)\end{array}$} & \multicolumn{2}{c}{ Ab-CX1 } & \multicolumn{2}{c}{ Ab-CX2 } \\
\cline { 2 - 5 } & $k$-values $\left(\mathrm{min}^{-1}\right)$ & $\mathrm{t}_{1 / 2}(\mathrm{~min})$ & $k$-values $\left(\mathrm{min}^{-1}\right)$ & $\mathrm{t}_{1 / 2}(\min )$ \\
\hline 50 & $0.0103 \pm 0.0003^{\mathrm{d}}$ & $67.28 \pm 2.06^{\mathrm{g}}$ & $0.0149 \pm 0.0007^{\mathrm{ab}}$ & $46.51 \pm 1.98^{\mathrm{c}}$ \\
55 & $0.0174 \pm 0.0004^{\mathrm{c}}$ & $39.82 \pm 1.92^{\mathrm{f}}$ & $0.0239 \pm 0.0005^{\mathrm{e}}$ & $28.99 \pm 0.95^{\mathrm{b}}$ \\
60 & $0.0215 \pm 0.0001^{\mathrm{e}}$ & $32.23 \pm 1.05^{\mathrm{e}}$ & $0.0340 \pm 0.0001^{\mathrm{h}}$ & $20.02 \pm 1.71^{\mathrm{a}}$ \\
65 & $0.1217 \pm 0.0005^{\mathrm{b}}$ & $17.63 \pm 0.07^{\mathrm{a}}$ & $0.0416 \pm 0.0003^{\mathrm{de}}$ & $16.65 \pm 0.04^{\mathrm{f}}$ \\
\hline
\end{tabular}


Results showed that the rate of $k$-value increased, indicating the thermostabilizing nature of carboxymethylcellulose, as a lower rate constant means the enzyme is more thermostable (Marangoni, 2002). The half-life $\left(\mathrm{t}_{1 / 2}\right)$ is another parameter that plays an important role in the characterization of enzyme stability (Arogba et al., 1998). As shown in Table 2, $\mathrm{t}_{1 / 2}$ determinations are more accurate and reliable on thermostability. With the increasing temperature, the $\mathrm{t}_{1 / 2}$ decreased and showed values ranged between $67.28 \pm 2.06$ and $17.63 \pm 0.07 \mathrm{~min}$ for Ab-CX1, and between $46.51 \pm 1.98$ and $16.65 \pm 0.04 \mathrm{~min}$ for $\mathrm{Ab}-\mathrm{CX} 2$. This would indicate that the enzymes are unstable at higher temperature (Lappe, et al., 2009). The increase in half-life by 1.6 fold for $\mathrm{Ab}-\mathrm{CX} 1$ at $60^{\circ} \mathrm{C}$ clearly indicates that Ab-CX1 was more stable. Also, the decimal reduction time ( $D$-value) needed for $90 \%$ reduction of the initial enzyme activity was calculated.

The corresponding $D$-values for $\mathrm{Ab}-\mathrm{CX} 1$ and $\mathrm{Ab}-\mathrm{CX} 2$ are given in Table 3. $D$-values decreased with increasing temperature from 50 to $65^{\circ} \mathrm{C}$, indicating a faster inactivation of carboxylmethylcellulases at higher temperatures. Similarly to the work of Sant'anna et al. (2011), thermal stability of peptide P34 decreased at higher temperature. $D$-values for Ab-CX1 and Ab-CX2 ranged from $223.59 \pm 4.74$ to $58.60 \pm 0.96 \mathrm{~min}$ and $154.56 \pm 2.64$ to $55.36 \pm 2.02$ min, respectively. It should be noted that at $60^{\circ} \mathrm{C}$, the $D$-value for $\mathrm{Ab}-\mathrm{CX} 1$ inactivation was 2 times higher than the corresponding value for $\mathrm{Ab}-\mathrm{CX} 2$ inactivation. This is probably due to the relative higher thermal stability of Ab-CX1.

The effect of temperature on $D$ - and $Z$-values of carboxymethylcellulases Ab-CX1 and Ab-CX2 from little soldier of Macrotermes subhyalinus are shown in Table 3.

Table 3. $D$-, $Z$ - and $E a$-values for thermal inactivation of carboxymethylcellulases Ab-CX1 and Ab-CX2 from little soldier of Macrotermes subhyalinus at temperature range $\left(50-65^{\circ} \mathrm{C}\right)$

\begin{tabular}{ccc}
\hline Kinetic parameters & Ab-CX1 & Ab-CX2 \\
\hline$D$-values (min) & & \\
$\mathrm{D}_{50}$ & $223.59 \pm 4.74^{\mathrm{f}}$ & $154.56 \pm 2.64^{\mathrm{d}}$ \\
$\mathrm{D}_{55}$ & $132.35 \pm 1.92^{\mathrm{j}}$ & $96.35 \pm 3.75^{\mathrm{e}}$ \\
$\mathrm{D}_{60}$ & $107.11 \pm 2.94^{\mathrm{k}}$ & $66.56 \pm 1.54^{\mathrm{i}}$ \\
$\mathrm{D}_{65}$ & $58.60 \pm 0.96^{\mathrm{b}}$ & $55.36 \pm 2.02^{\mathrm{d}}$ \\
\hline$Z$-value $\left({ }^{\circ} \mathrm{C}\right)$ & $24.21 \pm 1.92^{\mathrm{a}}$ & $33.33 \pm 2.78^{\mathrm{b}}$ \\
\hline$E a\left({\left.\mathrm{~kJ} . \mathrm{mol}^{-1}\right)}^{\mathrm{b}}\right)$ & $76.74 \pm 1.98^{\mathrm{b}}$ & $62.80 \pm 2.05^{\mathrm{c}}$ \\
\hline
\end{tabular}

The $Z$-values were calculated and found to be $24.21 \pm 1.92$ and $33.33 \pm 2.78{ }^{\circ} \mathrm{C}$ for $\mathrm{Ab}-\mathrm{CX} 1$ and $\mathrm{Ab}-\mathrm{CX} 2$, respectively at $50-65^{\circ} \mathrm{C}$. Thus the $Z$-value of $\mathrm{Ab}-\mathrm{CX} 1$ was lower compared to that of $\mathrm{Ab}-\mathrm{CX} 2$. The $Z$-values for cooking and nutrients degradation $\left(25-45^{\circ} \mathrm{C}\right)$ are generally greater than microbial inactivation $\left(7-12^{\circ} \mathrm{C}\right)$ (Awuah et al., 2007). In fact, differences between the $D$ - and $Z$-values of enzyme and nutrients are exploited to optimize thermal processes and can be exploited also to maintain carboxymethylcellulases activity after treatment. This indicates that any change in temperature processing affects more intensely the stability of Ab-CX1 than Ab-CX2. In this study, $D$-, $Z$ - and $k$-values indicate that both carboxylmethylcellulases are heat stable and then can be used in high temperature short time (HTST) and low temperature long time (LTLT) industrial processes such as pasteurization, where values of $65^{\circ} \mathrm{C}$ for $3-5 \mathrm{~min}$ and $55^{\circ} \mathrm{C}$ for $30 \mathrm{~min}$, respectively, are generally considered. In fact the $D$ - and $Z$-values of carboxylmethylcellulases are exploited to optimize thermal processes and to preserve enzyme activity after treatment. According to Barrett et al. (1999), high $Z$-values indicate more sensitivity to the heat treatment time and low $Z$-values indicate more sensitivity to increasing temperature.

In order to determine the thermodynamic parameters for thermal stability, the energy of activation $(E a)$ for thermal denaturation was determined by applying the Arrhenius plot. The $E a$ can be seen as the energy absorbed or released needed to the molecules be able to react (Van Boekel, 2008). In this study, from 50 to $65^{\circ} \mathrm{C}$, the carboxylmethylcellulase activation energy values were calculated to be $76.74 \pm 1.98$ and $62.80 \pm 2.05 \mathrm{~kJ} \cdot \mathrm{mol}^{-1}$ for $\mathrm{Ab}-\mathrm{CX} 1$ and Ab-CX2, respectively (Table 3). Thus, $\mathrm{Ab}-\mathrm{CX} 1$ in the presence of carboxymethylcellulose substrate displayed relatively higher energy barrier $\left(76.74 \pm 1.98 \mathrm{~kJ} \mathrm{~mol}^{-1}\right)$ than Ab-CX2 $\left(62.80 \pm 2.05 \mathrm{~kJ} \mathrm{~mol}^{-1}\right)$. Obviously, $\mathrm{Ab}-\mathrm{CX} 2$ showed a considerably higher thermosensitivity upon heat treatment. These values were lower than those of endoglucanase from Humicolain solens $\left(108.69 \mathrm{~kJ}^{\mathrm{mol}}{ }^{-1}\right)$ and of beta-glucosidase from Cardisoma armatum $\left(172.98 \mathrm{~kJ} \mathrm{~mol}^{-1}\right)$ (Riaz et al., 2014; Ya, et al., 2014). However, they were higher than an intracellular beta-glucosidase from a mutant-derivative of $C$. biazotea $\left(57 \mathrm{~kJ} \mathrm{~mol}^{-1}\right)$ (Rajoka et al., 2004). Both carboxylmethylcellulases (Ab-CX1 and Ab-CX2) had high relative activation energy values, which could indicate an increased stability at higher temperatures and that the enzyme conformation was still stable at these 
temperatures (Leite et al., 2007). The higher value of $E a$ means more energy is required to denature the treated enzyme as postulated by Tayefi-Nasrabadi and Asadpour (2008).

\subsection{Thermodynamic Studies of Carboxylmethylcellulases}

Thermostability represents the capability of an enzyme molecule to resist against thermal unfolding in the absence of substrate, while thermophilicity is the ability of an enzyme to work at elevated temperatures in the presence of substrate (Georis et al., 2000; Sarath Babu et al., 2004; Bhatti et al., 2013). Thermal inactivation may occur in two steps as shown below:

$$
N \leftrightarrow U \rightarrow I
$$

Where $N$ is the native, $U$ is the unfolded enzyme, which could be reversibly refolded upon cooling, and $I$ is the inactivated enzyme formed after prolonged exposure to heat, and therefore, cannot be recovered on cooling. The thermal denaturation of enzymes is accompanied by the disruption of non-covalent linkages, including hydrophobic interactions, with concomitant increase in the enthalpy of activation (Srivastava et al., 2005). The opening up of the enzyme structure is accompanied by an increase in the disorder, randomness or entropy of activation (Vieille \& Zeikus, 1996).

In the study of the mechanism of thermal inactivation of proteins, valuable information can be obtained by identifying some inactivation parameters, such as enthalpy $\left(\Delta H^{\sharp}\right)$, entropy $\left(\Delta S^{\#}\right)$ and Gibbs free energy $\left(\Delta G^{\#}\right)$. Thus, the determination of these thermodynamic parameters was carried out by measuring the carboxylmethylcellulase activities at different temperatures $\left(50-65^{\circ} \mathrm{C}\right)$. Table 4 shows these thermodynamics parameters for carboxylmethylcellulases Ab-CX1 and Ab-CX2.

Table 4. Thermodynamic parameters of carboxymethylcellulases Ab-CX1 and Ab-CX2 from little soldier of Macrotermes subhyalinus under heat treatment between 50 and $65^{\circ} \mathrm{C}$ (assuming a 1st-order kinetic model)

\begin{tabular}{|c|c|c|c|c|c|c|}
\hline \multirow{3}{*}{$\begin{array}{c}\text { Temperature } \\
\left({ }^{\circ} \mathrm{C}\right) \\
\end{array}$} & \multicolumn{6}{|c|}{ Thermodynamic parameters } \\
\hline & \multicolumn{2}{|c|}{$\Delta H^{\#}\left(\mathrm{~kJ} \cdot \mathrm{mol}^{-1}\right)$} & \multicolumn{2}{|c|}{$\Delta S^{\#}\left(\mathrm{~J} . \mathrm{mol}^{-1} \mathrm{~K}^{-1}\right)$} & \multicolumn{2}{|c|}{$\Delta G^{\sharp}\left(\mathrm{kJ} . \mathrm{mol}^{-1}\right)$} \\
\hline & $\mathrm{Ab}-\mathrm{CX} 1$ & $\mathrm{Ab}-\mathrm{CX} 2$ & $\mathrm{Ab}-\mathrm{CX} 1$ & $\mathrm{Ab}-\mathrm{CX} 2$ & $\mathrm{Ab}-\mathrm{CX} 1$ & $\mathrm{Ab}-\mathrm{CX} 2$ \\
\hline 50 & $74.06 \pm 0.02^{\mathrm{f}}$ & $60.12 \pm 0.02^{\mathrm{d}}$ & $190.10 \pm 0.01^{\mathrm{n}}$ & $21.72 \pm 0.02^{\mathrm{a}}$ & $12.63 \pm 0.02^{\mathrm{e}}$ & $53.10 \pm 0.02$ \\
\hline 55 & $74.02 \pm 0.01^{\mathrm{e}}$ & $60.08 \pm 0.01^{\mathrm{e}}$ & $189.97 \pm 0.02^{\mathrm{m}}$ & $21.59 \pm 0.02^{b}$ & $11.68 \pm 0.01^{\mathrm{f}}$ & $52.99 \pm 0.02$ \\
\hline 60 & $73.98 \pm 0.01^{\mathrm{h}}$ & $60.04 \pm 0.01^{\mathrm{c}}$ & $189.85 \pm 0.02^{\mathrm{k}}$ & $21.46 \pm 0.01^{\mathrm{c}}$ & $10.73 \pm 0.02^{\mathrm{g}}$ & $52.88 \pm 0.01^{\mathrm{b}}$ \\
\hline 65 & $73.93 \pm 0.02^{\mathrm{g}}$ & $59.99 \pm 0.02^{\mathrm{b}}$ & $189.72 \pm 0.01^{1}$ & $21.34 \pm 0.02^{\mathrm{d}}$ & $9.78 \pm 0.01^{\mathrm{h}}$ & $52.78 \pm 0.02^{\circ}$ \\
\hline Mean & $74.00 \pm 0.03^{k}$ & $60.06 \pm 0.01^{1}$ & $189.91 \pm 0.03^{\mathrm{k}}$ & $21.53 \pm 0.01^{\mathrm{b}}$ & $11.20 \pm 0.01^{\mathrm{f}}$ & $52.94 \pm 0.02$ \\
\hline
\end{tabular}

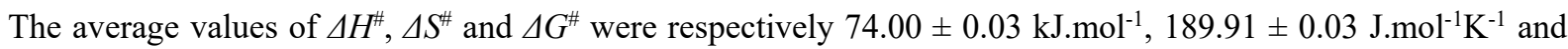
$11.20 \pm 0.01 \mathrm{~kJ}^{2} \mathrm{~mol}^{-1}$ for Ab-CX1 and $60.06 \pm 0.02 \mathrm{~kJ} \mathrm{~mol}^{-1}, 21.53 \pm 0.01 \mathrm{JJmol}^{-1} \mathrm{~K}^{-1}$ and $52.94 \pm 0.02 \mathrm{~kJ}^{-\mathrm{mol}^{-1}}$ for $\mathrm{Ab}-\mathrm{CX} 2$. Results also show that the Ab-CX1 enthalpy was higher than that of Ab-CX2. The high enthalpy $\left(\Delta H^{*}\right)$ change in the system clearly indicates that more energy is required for thermal denaturation of enzyme (Bhatti et al., 2005). The observed change in $\Delta H^{\#}$ also indicates that enzyme undergoes considerable change in conformation at higher temperatures even after treatment (Marín et al., 2003). In this study, the positive value of this parameter indicates that the catalytic reaction is endothermic.

According to Anema and Mckenna (1996), the positive values of entropy $\left(\Delta S^{\#}\right)$ for the hydrolysis reaction of carboxymethylcellulose indicate that the reaction proceeds with less speed and is characterized by low regularity. Small changes in the values of $\Delta S^{\#}$ indicates a preferential destruction of weak bonds (hydrogen and electrostatic), resulting in a lower loss of catalytic activity. The positive values for change in $\Delta S^{\#}$ also indicate that there are no significant processes of aggregation for both carboxylmethylcellulases. Furthermore, the high values obtained for $\Delta S^{\#}$ variation probably reflect an increased disorder of the active site or the structure of each carboxylmethylcellulase, which is the main driving force of heat denaturation (D'amico et al., 2003). Generally, activation entropy has a dominant role in thermal inactivation of proteins in aqueous solutions (Bromberg et al., 2008).

The Gibbs free energy change $\left(\Delta G^{\sharp}\right)$ indicates the spontaneity of the reaction catalyzed under the conditions of temperature and pressure used. In this study, $\Delta G^{\#}$ values were positive, indicating that the processes were endergonic and not spontaneous. 


\section{Conclusion}

Based on an isothermal experiment in the temperature range from 50 to $65^{\circ} \mathrm{C}$ and using Arrhenius equation, the thermal inactivation of carboxymethylcellulases $\mathrm{Ab}-\mathrm{CX} 1$ and $\mathrm{Ab}-\mathrm{CX} 2$ can be explained by the first-order model. The $D-, Z-, k$-values, indicate that $\mathrm{Ab}-\mathrm{CX} 1$ and $\mathrm{Ab}-\mathrm{CX} 2$ are heat stable and then could be utilized in pasteurization conditions, maintaining part of their biological activity. The high values obtained for activation energy $(E a)$ and change in enthalpy $\left(\Delta H^{\sharp}\right)$ indicated that a high amount of energy was needed to initiate denaturation of these carboxylmethylcellulases, most likely due to its stable molecular conformation.

\section{Acknowledgments}

The authors thanks to the Laboratory of Biocatalysis and Bioprocessing at the University Nangui Abrogoua (Abidjan, Côte d'Ivoire) for technical assistance and for financial support.

\section{References}

Adsul, M. G., Bastawde, K. B., Varma, A. J., \& Gokhale, D. V. (2007). Strain improvement of Penicillium janthinellum NCIM 1171 for increased cellulase production. Bioresource Technology, 98(7), 1467-1473. http://dx.doi.org/10.1016/j.biortech.2006.02.036

Anema, S. G., \& McKenna, A. B. (1996). Reaction kinetics of thermal denaturation of whey proteins in heated reconstituted whole milk. Journal of Agricultural and Food Chemistry, 44(2), 422-428. https://doi.org/10.1021/j950217q

Arakawa, G., Watanabe, H., Yamasaki, H., Maekawa, H., \& Tokuda, G. (2009). Purification and molecular cloning of xylanases from the wood-feeding termite, Coptotermes formosanus Shiraki. Bioscience, Biotechnology, and Biochemistry, 73(3), 710-718. https://doi.org/10.1271/bbb.80788

Arogba, S. S., Ajiboye, O. L., Ugboko, L. A., Essienette, S. Y., \& Afolabi, P. O. (1998). Properties of polyphenol oxidase in mango (Mangifera indica) kernel. Journal of the Science of Food and Agriculture, 77(4), 459-462. https://doi.org/10.1002/(SICI)1097-0010(199808)77:4<459::AID-JSFA61>3.0.CO;2-O

Awuah, G. B., Ramaswamy, H. S., \& Economides, A. (2007). Thermal processing and quality: Principles and overview. Chemical Engineering and Processing: Process Intensification, 46(6), 584-602. http://dx.doi.org/10.1016/j.cep.2006.08.004

Barrett, N. E., Grandison, A. S., \& Lewis, M. J. (1999). Contribution of the lactoperoxidase system to the keeping quality of pasteurized milk. Journal of Dairy Research, 66(1), 73-80.

Bhatti, H. N., Batool, S., \& Afzal, N. (2013). Production and characterization of a novel beta-glucosidase from Fusarium solani. International Journal of Agriculture and Biology, 15, 140-144.

Bhatti, H. N., Zia, A., Nawaz, R., Sheikh, M. A., Rashid, M. H., \& Khalid, A. M. (2005). Effect of copper ions on thermal stability of glucoamylase from Fusarium sp. International Journal of Agriculture and Biology, 7, 585-587.

Binate, S., N'dri, D., Toka, M., \& Kouamé, L. P. (2008). Purification and characterization of two beta-glucosidases from termite workers Macrotermes bellicosus (Termitidae: Macrotermitinae). Journal of Applied Biosciences, 10(1), 461-470.

Blei, H. S., Soro, R. Y., Dabonne, S., \& Patrice, K. (2010). A novel polysaccharidase with endo-beta-D-xylanase and endo-beta-D-glucanase activities in the gut of the major soldier of the termite Macrotermes subhyalinus. Journal of Animal and Plant Sciences, 8, 912-926.

Bromberg, A., Marx, S., \& Frishman, G. (2008). Kinetic study of the thermal inactivation of cholinesterase enzymes immobilized in solid matrices. Biochimica et Biophysica Acta (BBA) - Proteins and Proteomics, 1784(6), 961-966. http://dx.doi.org/10.1016/j.bbapap.2008.02.018

Criswell, A. R., Bae, E., Stec, B., Konisky, J., \& Phillips Jr, G. N. (2003). Structures of thermophilic and mesophilic adenylate kinases from the genus methanococcus. Journal of Molecular Biology, 330(5), 1087-1099. http://dx.doi.org/10.1016/S0022-2836(03)00655-7

D'Amico, S., Marx, J.-C., Gerday, C., \& Feller, G. (2003). Activity-stability relationships in extremophilic enzymes. Journal of Biological Chemistry, 278(10), 7891-7896. https://doi.org/10.1074/jbc.M212508200

De Almeida, M. N., Guimarães, V. M., Bischoff, K. M., Falkoski, D. L., Pereira, O. L., Gonçalves, D. S. P. O., \& de Rezende, S. T. (2011). Cellulases and hemicellulases from endophytic Acremonium species and its 
application on sugarcane bagasse hydrolysis. Applied Biochemistry and Biotechnology, 165(2), 594-610. https://doi.org/10.1007/s12010-011-9278-z

Dogan, M., Arslan, O., \& Dogan, S. (2002). Substrate specificity, heat inactivation and inhibition of polyphenol oxidase from different aubergine cultivars. International Journal of Food Science \& Technology, 37(4), 415-423. https://doi.org/10.1046/j.1365-2621.2002.00580.x

Egas, M. C. V., da Costa, M. S., Cowan, D. A., \& Pires, E. M. V. (1998). Extracellular $\alpha$-amylase from Thermus filiformis Ork A2: purification and biochemical characterization. Extremophiles, 2(1), 23-32. https://doi.org/10.1007/s007920050039

Elcock, A. H. (1998). The stability of salt bridges at high temperatures: implications for hyperthermophilic proteins11Edited by B. Honig. Journal of Molecular Biology, 284(2), 489-502. http://dx.doi.org/10.1006/jmbi.1998.2159

Espachs-Barroso, A., Van Loey, A., Hendrickx, M., \& Martín-Belloso, O. (2006). Inactivation of plant pectin methylesterase by thermal or high intensity pulsed electric field treatments. Innovative Food Science \& Emerging Technologies, 7(1), 40-48. http://dx.doi.org/10.1016/j.ifset.2005.07.002

Fagbohoun, J. B. (2013). Propriétés biochimiques, analyses cinétique et thermodynamique des enzymes responsables de la cellulolyse et de la xylanolyse chez le petit soldat du termite Macrotermes subhyalinus (Termitidae, Macrotermitinae) (Unpublished doctoral dissertation). University Nangui Abrogoua, Abidjan, Côte d'Ivoire.

Fagbohoun, J. B., Ahi, A. P., Karamoko, Y., Dabonné, S., Kouadio, E. J. P., \& Kouamé, L. P. (2012). An endo-beta-D-glycosidase from salivary glands of Macrotermes subhyalinus little soldier with a dual activity against carboxymethylcellulose and xylan. International Journal of Biosciences, 2, 1-10.

Fagbohunka, B. S., Okonji, R. E., \& Adenike, A. Z. (2017). Purification and characterization of cellulase from termite Ametermes eveuncifer (Silverstri) soldiers. International Journal of Biology, 9, 1-9. http://dx.doi.org/10.5539/ijb.v9n1p1

Gaffney, M., Carberry, S., Doyle, S., \& Murphy, R. (2009). Purification and characterisation of a xylanase from Thermomyces lanuginosus and its functional expression by Pichia pastoris. Enzyme and Microbial Technology, 45(5), 348-354. http://dx.doi.org/10.1016/j.enzmictec.2009.07.010

George, S. P., Ahmad, A., \& Rao, M. B. (2001). A novel thermostable xylanase from Thermomonospora sp.: influence of additives on thermostability. Bioresource Technology, 78(3), 221-224. http://dx.doi.org/10.1016/S0960-8524(01)00029-3

Georis, J., de Lemos Esteves, F., Lamotte-Brasseur, J., Bougnet, V., Devreese, B., Giannotta, F., . . Frère, J. M. (2000). An additional aromatic interaction improves the thermostability and thermophilicity of a mesophilic family 11 xylanase: structural basis and molecular study. Protein Science, 9(3), 466-475. https://doi.org/10.1110/ps.9.3.466

Guiavarc'h, Y. P., Deli, V., Van Loey, A. M., \& Hendrickx, M. E. (2002). Development of an enzymic time temperature integrator for sterilization processes based on Bacillus licheniformis $\alpha$-amylase at reduced water content. Journal of Food Science, 67(1), 285-291.https://doi.org/10.1111/j.1365-2621.2002.tb11399.x

Haruta, S., Cui, Z., Huang, Z., Li, M., Ishii, M., \& Igarashi, Y. (2002). Construction of a stable microbial community with high cellulose-degradation ability. Applied Microbiology and Biotechnology, 59(4), 529-534. https://doi.org/10.1007/s00253-002-1026-4

Hong, Y., Dashtban, M., Chen, S., Song, R., \& Qin, W. (2012). Enzyme production and lignin degradation by four basidiomycetous fungi in submerged fermentation of peat containing medium. International Journal of Biology, 4, 172-180. http://dx.doi.org/10.5539/ijb.v4n1p172

Hopfner, K.-P., Eichinger, A., Engh, R. A., Laue, F., Ankenbauer, W., Huber, R., \& Angerer, B. (1999). Crystal structure of a thermostable type B DNA polymerase from Thermococcus gorgonarius. Proceedings of the National Academy of Sciences of the United States of America, 96(7), 3600-3605.

Jabbar, A., Rashid, M. H., Javed, M. R., Perveen, R., \& Malana, M. A. (2008). Kinetics and thermodynamics of a novel endoglucanase (CMCase) from Gymnoascella citrina produced under solid-state condition. Journal of Industrial Microbiology \& Biotechnology, 35(6), 515-524. https://doi.org/10.1007/s10295-008-0310-4 
Kaur, J., Chadha, B. S., Kumar, B. A., \& Saini, H. S. (2007). Purification and characterization of two endoglucanases from Melanocarpus sp. MTCC 3922. Bioresource Technology, 98(1), 74-81. http://dx.doi.org/10.1016/j.biortech.2005.11.019

Kumar, H. D., \& Swati, S. (2001). Modern concepts of Microbiology (2nd revised ed.). Vikas Publishing House Pvt., New Delhi.

Lama, L., Calandrelli, V., Gambacorta, A., \& Nicolaus, B. (2004). Purification and characterization of thermostable xylanase and $\beta$-xylosidase by the thermophilic bacterium Bacillus thermantarcticus. Research in Microbiology, 155(4), 283-289. http://dx.doi.org/10.1016/j.resmic.2004.02.001

Lappe, R., Cladera-Olivera, F., Dominguez, A. P. M., \& Brandelli, A. (2009). Kinetics and thermodynamics of thermal inactivation of the antimicrobial peptide cerein 8A. Journal of Food Engineering, 91(2), 223-227. http://dx.doi.org/10.1016/j.jfoodeng.2008.08.025

Leite, R. S. R., Gomes, E., \& da Silva, R. (2007). Characterization and comparison of thermostability of purified $\beta$-glucosidases from a mesophilic Aureobasidium pullulans and a thermophilic Thermoascus aurantiacus. Process Biochemistry, 42(7), 1101-1106. http://dx.doi.org/10.1016/j.procbio.2007.05.003

Lowry, O. H., Rosebrough, N. J., Farr, A. L., \& Randall, R. J. (1951). Protein measurement with the folin phenol reagent. Journal of Biological Chemistry, 193(1), 265-275.

Macedo-Ribeiro, S., Darimont, B., Sterner, R., \& Huber, R. (1996). Small structural changes account for the high thermostability of $1[4 \mathrm{Fe}-4 \mathrm{~S}]$ ferredoxin from the hyperthermophilic bacterium Thermotoga maritima. Structure, 4(11), 1291-1301. http://dx.doi.org/10.1016/S0969-2126(96)00137-2

Marangoni, A. G. (2002). Characterization of Enzyme Stability, in Enzyme Kinetics: A Modern Approach. John Wiley \& Sons, Inc., Hoboken, NJ, USA. https://doi.org/10.1002/0471267295.ch12

Marín, E., Sánchez, L., Pérez, M. D., Puyol, P., \& Calvo, M. (2003). Effect of heat treatment on bovine lactoperoxidase activity in skim milk: kinetic and thermodynamic analysis. Journal of Food Science, 68(1), 89-93. https://doi.org/10.1111/j.1365-2621.2003.tb14120.x

Matsumoto, M., Kida, K., \& Kondo, K. (1997). Effects of polyols and organic solvents on thermostability of lipase. $\begin{array}{lllll}\text { Journal of Chemical Technology \& Biotechnology, } & 70(2), & \text { 188-192. }\end{array}$ https://doi.org/10.1002/(SICI)1097-4660(199710)70:2<188::AID-JCTB745>3.0.CO;2-X

Niaz, M., Iftikhar, T., \& Rashid, M. H. (2011). Carboxyl group modification of Gymnoascella citrina glucoamylase: Cross-linking with hydrophobic nucleophile enhanced thermostability and thermophilicity. Clinical Biochemistry, 44(13), S93-S94. https://doi.org/doi:10.1016/j.clinbiochem.2011.08.212

Ninawe, S., Kapoor, M., \& Kuhad, R. C. (2008). Purification and characterization of extracellular xylanase from

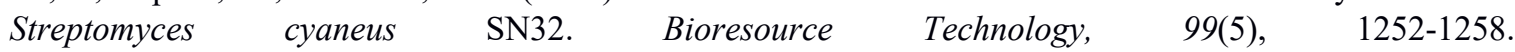
http://dx.doi.org/10.1016/j.biortech.2007.02.016

Ögel, Z. B., Yarangümeli, K., Dündar, H., \& Ifrij, İ. (2001). Submerged cultivation of Scytalidium thermophilum on complex lignocellulosic biomass for endoglucanase production. Enzyme and Microbial Technology, 28(7), 689-695. http://dx.doi.org/10.1016/S0141-0229(01)00315-5

Papinutti, V. L., \& Forchiassin, F. (2007). Lignocellulolytic enzymes from Fomes sclerodermeus growing in solid-state fermentation. Journal of Food Engineering, 81(1), 54-59. http://dx.doi.org/10.1016/j.jfoodeng.2006.10.006

Rajoka, M. I., Durrani, I. S., \& Khalid, A. M. (2004). Kinetics of improved production and thermostability of an intracellular beta-glucosidase from a mutant-derivative of Cellulomonas biazotea. Biotechnology Letters, 26(4), 281-285.

Riaz, H., Jabbar, A., Rashid, M. H., Riaz, S., \& Latif, F. (2014). Endoglucanase production by Humicola insolens: effect of physiochemical factors on growth kinetics and thermodynamics. International Journal of Agriculture and Biology, 16, 1141-1146.

Russell, R. J. M., Ferguson, J. M. C., Hough, D. W., Danson, M. J., \& Taylor, G. L. (1997). The crystal structure of citrate synthase from the hyperthermophilic archaeon Pyrococcus furiosus at 1.9 A resolution. Biochemistry, 36(33), 9983-9994. https://doi.org/10.1021/bi9705321

Sant'Anna, V., Utpott, M., Cladera-Olivera, F., \& Brandelli, A. (2011). Influence of pH and sodium chloride on kinetics of thermal inactivation of the bacteriocin-like substance P34. Journal of Applied Microbiology, 110(1), 156-162. https://doi.org/10.1111/j.1365-2672.2010.04868.x 
Sarath Babu, V. R., Kumar, M. A., Karanth, N. G., \& Thakur, M. S. (2004). Stabilization of immobilized glucose oxidase against thermal inactivation by silanization for biosensor applications. Biosensors and Bioelectronics, 19(10), 1337-1341. http://dx.doi.org/10.1016/j.bios.2003.11.024

Séa, T. B., Saki, S. J., Coulybaly, A., Yeboua, A. F., \& Diopoh, K. J. (2006). Extraction, purification et caractérisation de deux cellulases du termite Macrotermes subhyalinus (Termitidae). Agronomie Africaine, $10,57-65$.

Sousa, R. (1995). Use of glycerol, polyols and other protein structure stabilizing agents in protein crystallization. Acta Crystallographica Section D, 51, 271-277. https://doi.org/10.1107/s0907444994014009

Srivastava, R., Brown, J. Q., Zhu, H., \& McShane, M. J. (2005). Stabilization of glucose oxidase in alginate microspheres with photoreactive diazoresin nanofilm coatings. Biotechnology and bioengineering, 91(1), 124-131. https://doi.org/10.1002/bit.20469

Stauffer, C. E. (1989). Enzyme assays for food scientists (1st ed., pp. 67-78). New York, NY: Van Nostrand Reinhold

Stumbo, C. R. (1973). Thermobacteriology in food processing (2nd ed., p. 336). New York, NY: Academic Press.

Tayefi-Nasrabadi, H., \& Asadpour, R. (2008). Effect of heat treatment on buffalo (Bubalus bubalis) lactoperoxidase activity in raw milk. Journal of Biology Science, 8(8), 1310-1315. https://doi.org/10.3923/jbs.2008.1310.1315

Trasar-Cepeda, C., Gil-Sotres, F., \& Leirós, M. C. (2007). Thermodynamic parameters of enzymes in grassland soils from Galicia, NW Spain. Soil Biology and Biochemistry, 39(1), 311-319. http://dx.doi.org/10.1016/j.soilbio.2006.08.002

Van Boekel, M. A. J. S. (2008). Kinetic modeling of food quality: A critical review. Comprehensive Reviews in Food Science and Food Safety, 7(1), 144-158. https://doi.org/10.1111/j.1541-4337.2007.00036.x

Vetriani, C., Maeder, D. L., Tolliday, N., Yip, K. S. P., Stillman, T. J., Britton, K. L., . . Robb, F. T. (1998). Protein thermostability above $100^{\circ} \mathrm{C}$ : A key role for ionic interactions. Proceedings of the National Academy of Sciences of the United States of America, 95(21), 12300-12305.

Vieille, C., Burdette, D. S., \& Zeikus, J. G. (1996). Thermozymes. Biotechnology and Annual Review, 2, 1-83.

Vieille, C., \& Gregory Zeikus, J. (1996). Thermozymes: Identifying molecular determinants of protein structural

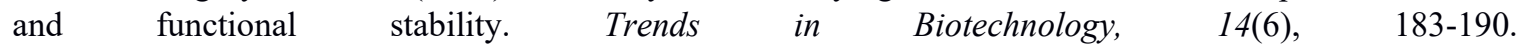
http://dx.doi.org/10.1016/0167-7799(96)10026-3

Walsh, G. (2002). Industrial enzymes: proteases and carbohydrases. In: Proteins, Biochemistry and Biotechnology. John Wiley and Sons, New York.

Xia, W., Liu, P., \& Liu, J. (2008). Advance in chitosan hydrolysis by non-specific cellulases. Bioresource Technology, 99(15), 6751-6762. http://dx.doi.org/10.1016/j.biortech.2008.01.011

Ya, K. C., Konan, K. H., Gnangui, S. N., \& Kouamé, L. P. (2014). Study of thermal stability of beta-glucosidase from the land crab digestive juice (Cardisoma armatum): kinetic and thermodynamic analysis. International Journal of Development Research, 4, 1836-1840.

Zaldivar, J., Nielsen, J., \& Olsson, L. (2001). Fuel ethanol production from lignocellulose: a challenge for metabolic engineering and process integration. Applied Microbiology and Biotechnology, 56(1-2), 17-34.

\section{Copyrights}

Copyright for this article is retained by the author(s), with first publication rights granted to the journal.

This is an open-access article distributed under the terms and conditions of the Creative Commons Attribution license (http://creativecommons.org/licenses/by/4.0/). 